\title{
ANALISIS RASIO LAPORAN KEUANGAN UNTUK MENILAI KINERJA KEUANGAN PADA PT BANK SUMUT
}

\author{
Eva Malina Simatupang \\ Politeknik Negeri Medan \\ email : evasimatupang14@gmail.com
}

\begin{abstract}
This study aims to assess the financial performance of PT Bank SUMUT in terms of liquidity ratios, profitability ratios, and solvency ratios in period 2015-2017. The type of data used in this study is secondary data, that is balance sheet and income statement. Data collection in this study uses documentation and data processing techniques using ratio analysis techniques. The conclusion of this study is in terms of its liquidity ratio, PT Bank SUMUT's financial performance is quite good, in terms of its profitability ratio, PT Bank SUMUT's financial performance is not good, and in terms of its solvency ratio, PT Bank SUMUT's financial performance is quite good.
\end{abstract}

Keywords: Financial Performance, Liquidity Ratio, Profitability Ratio, and Solvency Ratio

\section{PENDAHULUAN}

Menurut Mulyono dalam Wardiah (2013:283), untuk menilai kinerja keuangan perusahaan dapat diketahui dengan 3 (tiga) aspek, yaitu :

1. Rasio likuiditas, merupakan suatu perbandingan yang menggambarkan kemampuan perusahaan untuk membayar kewajiban-kewajiban jangka pendeknya

2. Rasio solvabilitas, merupakan perbandingan yang menggambarkan kemampuan perusahaan untuk memenuhi seluruh kewajiban finansialnya jika perusahaan dilikuidasi

3. Rasio rentabilitas, merupakan suatu perbandingan yang menggambarkan kemampuan perusahaan untuk menghasilkan keuntungan laba selama periode tertentu.

Munawir (2007:42) menyatakan bahwa analisis rasio dimulai dari analisis terhadap perubahan jumlah totalnya (misalnya perubahan jumlah aktiva), kemudian analisis terhadap perubahan subtotal (misalnya perubahan yang terjadi pada aktiva lancar, hutang lancar, aktiva lancar dan perubahan-perubahan subtotal lainnya) dan kemudian diadakan analisis terhadap perubahan-perubahan yang terjadi dalam masing-masing pos, dengan membandingkan atau menghubungkan antara perubahan yang satu dengan perubahan lainnya sehingga akhirnya akan dapat ditarik sebagai kesimpulan dari hasil analisis tersebut. Kinerja keuangan suatu perusahaan tidak dapat dinilai hanya berdasarkan laba yang dihasilkan. Maka, penulis tertarik untuk menganalisis bagaimana kinerja keuangan PT Bank SUMUT yang dihitung berdasarkan analisis rasio keuangan. Alasan mengapa penulis memilih analisis rasio, dikarenakan melalui analisis rasio penulis dapat melihat perkembangan perusahaan secara keseluruhan ditinjau dari rasio likuiditas, rasio solvabilitas, dan rasio profitabilitas.Berdasarkan uraian-uraian tersebut, maka penelitian ini diberi Judul "Analisis Rasio Laporan Keuangan untuk Menilai Kinerja Keuangan pada PT Bank SUMUT Periode 2015-2017”.

\section{Rumusan Masalah}

Berdasarkan latar belakang masalah yang sudah diuraikan di atas maka rumusan masalahnya adalah: "Bagaimana kinerja keuangan PT Bank SUMUT ditinjau dari rasio likuiditas, rasio rentabilitas, dan rasio solvabilitas pada periode 2015-2017? 


\section{Tujuan Penelitian}

Tujuan penelitian ini adalah untuk mengetahui kinerja keuangan PT Bank SUMUT ditinjau dari rasio likuiditas, rasio solvabilitas, dan rasio profitabilitas pada periode 2015-2017.

\section{TINJAUAN PUSTAKA}

Menurut Ismail (2010:15), bank adalah perusahaan yang bergerak dibidang jasa yang menyangkut bidang keuangan yang mempunyai 3(tiga) fungsi utama, yaitu:

1. Menghimpun dana dari masyarakat dalam bentuk simpanan giro, tabungan, deposito, dan simpanan lainnya yang diperkenankan.

2. Menyalurkan dana kepada masyarakat berupa kredit untuk bank konvensional dan pembiayaan untuk bank syariah.

3. Melaksanakan berbagai jenis produk pelayanan jasa yang dapat diberikan oleh bank antara lain jasa pengiriman uang (transfer), pemindahbukuan, jual beli surat berharga, kliring, Letter of Credit, inkaso, garansi bank dan lain-lain.

\section{Jenis-Jenis Rasio Keuangan}

Menurut Munawir (2007:31), dalam menganalisis dan menilai posisi keuangan serta potensi atau kemajuan perusahaan, faktor yang paling utama yang harus diperhatikan adalah:

1. Rasio Likuiditas

1. Rasio Solvabilitas

2. Rasio Rentabilitas/ profitability

3. Rasio Stabilitas Usaha

\section{Rasio Likuiditas}

Menurut Kasmir (2008:221), jenis-jenis rasio likuiditas adalah sebagai berikut :

a. Quick Ratio

b. Investing Policy Ratio

c. Banking Ratio

d. Assets to Loan Ratio

e. Cash Ratio

f. Loan to Deposit Ratio

\section{Rasio Rentabilitas}

Menurut Kasmir (2008:235), jenis-jenis rasio rentabilitas adalah sebagai berikut :

1. Gross Profit Margin

2. Net Profit Margin

3. Return on Equity Capital

4. Return on Total Assets

5. Rate Return on Loan

6. Interest Margin on Earning Assets

7. Interest Margin on Loan

8. Leverage Multiplier

9. Assets Utilization

10. Interest Expense Ratio

11. Cost of Fund

12. Cost of Money

13. Cost of Loanable Fund

14. Cost of Operable Fund

15. Cost of Efficiency 


\author{
Rasio Solvabilitas \\ Menurut Kasmir (2008 : 229) Jenis-jenis rasio Solvabilitas yaitu : \\ 1.Primary Ratio \\ 2.Risk Assets Ratio \\ 3.Secondary Risk Ratio \\ 4. Capital Ratio \\ 5.Capital Adequancy Ratio
}

\title{
METODE
}

\section{Populasi dan Sampel}

Dalam penelitian ini populasi yang digunakan adalah laporan keuangan PT Bank SUMUT. Sampel yang digunakan dalam penelitian ini adalah laporan keuangan PT Bank SUMUT, yaitu laporan posisi keuangan dan laporan laba rugi periode 2015 sampai dengan 2017.

\section{Jenis Data}

Data sekunder dalam penelitian ini adalah laporan tahunan PT Bank SUMUT periode 2015 sampai dengan 2017. Dalam penelitian ini, data tersebut diperoleh dari laporan keuangan publikasi bank pada website Otoritas Jasa Keuangan (OJK) yaitu www.ojk.go.id

\section{PEMBAHASAN}

\section{Rasio Likuiditas}

Rasio likuiditas merupakan rasio yang digunakan untuk mengukur kemampuan bank dalam memenuhi kewajiban jangka pendeknya pada saat ditagih. Dengan kata lain, bank dapat membayar kembali pencairan dana para deposannya pada saat ditagih serta dapat mencukupi permintaan kredit yang telah diajukan. Makin besar rasio ini, makin likuid.

\section{Quick Ratio}

Dari pengolahan data yang telah dilakukan, dapat diketahui bahwa besar Quick Rasio atau Rasio Cepat, yaitu rasio total cash assets dengan total deposits PT Bank SUMUT pada tahun 2015 adalah 20,69\%, tahun 2016 adalah 21,97\%, dan tahun 2017 adalah 17,99\%. Dari hasil perhitungan tersebut dapat dilihat peningkatan antara tahun 2015 dan tahun 2016 sebesar 1,28\%, hal ini diakibatkan peningkatan total aset dari Rp.3.754.492 menjadi Rp.4.218.522 dan peningkatan total deposit dari Rp.18.144.550 menjadi Rp.19.198.858. Pada tahun 2016 ke tahun 2017 mengalami penurunan sebesar 3,98\%, hal ini diakibatkan oleh penurunan cash asset dari Rp.4.218.522 menjadi Rp.3.811.336 dan total deposit mengalami peningkatan dari Rp.19.198.858 menjadi Rp.21.187.317. Dilihat dari Quick Ratio PT Bank SUMUT tahun 2015 sampai 2017 kinerja perusahaan cukup baik.

\section{Investing Policy Ratio}

Dari pengolahan data yang telah dilakukan, dapat diketahui bahwa besar Investing Policy Ratio, yaitu rasio total Securities dengan total deposits PT Bank SUMUT pada tahun 2015 adalah 10,86\%, tahun 2016 adalah 11,19\%, dan tahun 2017 adalah 19,06\%. Dari hasil perhitungan tersebut dapat dilihat peningkatan antara tahun 2015 dan tahun 2016 sebesar 0,33\%, hal ini diakibatkan peningkatan total securities dari Rp.1.070.422 menjadi Rp.2.148.272 dan peningkatan total deposit dari Rp.18.144.550 menjadi Rp.19.198.858. Pada tahun 2016 ke tahun 2017 mengalami peningkatan sebesar 7,87\%, hal ini diakibatkan oleh peningkatan securities dari Rp.2.148.272 menjadi Rp.4.038.036 dan total deposit mengalami peningkatan dari Rp.19.198.858 menjadi Rp.21.187.317. Dilihat dari Investing Policy Ratio PT Bank SUMUT 
tahun 2015 sampai 2017 mempunyai kinerja yang baik karena mengalami peningkatan dari tahun 2015 sampai 2017.

\section{Banking Ratio}

Dari pengolahan data yang telah dilakukan, dapat diketahui bahwa besar Banking Rasio, yaitu rasio total loans dengan total deposits PT Bank SUMUT pada tahun 2015 adalah 93,37\%, tahun 2016 adalah 91,54\%, dan tahun 2017 adalah 87,15\%. Dari hasil perhitungan tersebut dapat dilihat terjadi penurunan rasio dari tahun 2015 ke tahun 2016 sebesar 1,83\%, hal ini diakibatkan peningkatan total loans dari Rp.16.941.434 menjadi Rp.17.574.079 dan peningkatan total deposit dari Rp.18.144.550 menjadi Rp.19.198.858. Pada tahun 2016 ke tahun 2017 mengalami penurunan rasio sebesar 4,39\%, hal ini diakibatkan oleh peningkatan total loans dari Rp.17.574.079 menjadi Rp18.465.683 dan peningkatan total deposit dari Rp.19.198.858 menjadi Rp.21.187.317. Dilihat dari Banking Ratio PT Bank SUMUT tahun 2015 sampai 2017 kinerja perusahaan baik karena mengalami penurunan rasio setiap tahunnya, karena semakin rendah rasio ini, tingkat likuiditas bank makin tinggi karena jumlah dana yang digunakan untuk membiayai kredit semakin besar.

\section{Assets to Loan Ratio}

Dari pengolahan data yang telah dilakukan, dapat diketahui bahwa besar Assets to Loan Ratio, yaitu rasio total loans dengan total assets PT Bank SUMUT pada tahun 2015 adalah 70,21\%, tahun 2016 adalah 67,15\%, dan tahun 2017 adalah 63,82\%. Dari hasil perhitungan tersebut dapat dilihat terjadi penurunan rasio dari tahun 2015 ke tahun 2016 sebesar 3,06\%, hal ini diakibatkan peningkatan total loans dari Rp.16.941.434 menjadi Rp.17.574.079 dan peningkatan total aset dari Rp.24.130.113 menjadi Rp.26.170.044. Pada tahun 2016 ke tahun 2017 mengalami penurunan rasio sebesar 3,33\%, hal ini diakibatkan oleh peningkatan total loans dari Rp.17.574.079 menjadi Rp18.465.683 dan peningkatan total aset dari Rp. 26.170.044 menjadi Rp.28.931.824. Dilihat dari Assets to Loan Ratio PT Bank SUMUT tahun 2015 sampai 2017 kinerja perusahaan baik karena mengalami penurunan rasio setiap tahunnya, karena semakin rendah rasio ini, tingkat likuiditas bank makin tinggi karena jumlah harta atau aset yang digunakan untuk membiayai kredit semakin besar.

\section{Cash Ratio}

Dari pengolahan data yang telah dilakukan, dapat diketahui bahwa besar Cash Rasio, yaitu rasio total liqiud assets dengan short term borrowing PT Bank SUMUT pada tahun 2015 adalah 13,71\%, tahun 2016 adalah 15,61\%, dan tahun 2017 adalah 14,24\%. Dari hasil perhitungan tersebut dapat dilihat peningkatan antara tahun 2015 dan tahun 2016 sebesar 1,90\%, hal ini diakibatkan peningkatan total liquid assets dari Rp.2.551.882 menjadi Rp.3.120.228 dan peningkatan short term borrowing dari Rp.18.611.183 menjadi Rp.19.990.483. Pada tahun 2016 ke tahun 2017 mengalami penurunan sebesar 1,37\%, hal ini diakibatkan oleh penurunan liquid assets dari Rp. Rp.3.120.228 menjadi Rp.3.063.608 dan short term borrowing mengalami peningkatan dari Rp.19.990.483 menjadi Rp.21.513.080. Dilihat dari Cash Ratio PT Bank SUMUT tahun 2015 sampai 2017 kinerja perusahaan cukup baik.

\section{Loan to Deposit Ratio}

Dari pengolahan data yang telah dilakukan, dapat diketahui bahwa besar Loan to Deposit Rasio, yaitu rasio total loans dengan total deposits ditambahkan dengan total Equity PT Bank SUMUT pada tahun 2015 adalah 84,13\%, tahun 2016 adalah 80,18\%, dan tahun 2017 adalah $76,36 \%$. Dari hasil perhitungan tersebut dapat dilihat terjadi penurunan rasio dari tahun 2015 ke tahun 2016 sebesar 3,95\%, hal ini diakibatkan peningkatan total loans dari Rp.16.941.434 menjadi Rp.17.574.079 dan peningkatan total deposit dengan total ekuitas dari Rp.20.136.967 menjadi Rp.21.918.007. Pada tahun 2016 dan tahun 2017 mengalami penurunan rasio sebesar 3,82\%, hal ini diakibatkan oleh peningkatan total loans dari Rp.17.574.079 menjadi Rp18.465.683 dan peningkatan total deposit dan total ekuitas dari Rp.21.918.007 
menjadi Rp.24.181.890. Dilihat dari Loan to Deposit Ratio PT Bank SUMUT tahun 2015 sampai 2017 kinerja perusahaan baik karena mengalami penurunan rasio setiap tahunnya, karena semakin rendah rasio ini, tingkat likuiditas bank makin tinggi karena jumlah dana dari masyarakat dan modal sendiri yang digunakan untuk membiayai kredit semakin besar.

\section{Rasio Rentabilitas \\ Gross Profit Margin}

Dari pengolahan data yang telah dilakukan, dapat diketahui bahwa besar Gross Profit Margin (GPM) yaitu rasio antara operating income dikurangi operating expense dengan operating income PT Bank SUMUT pada tahun 2015 adalah 17,84\%, tahun 2016 adalah 20,46\%, dan tahun 2017 adalah 21,88\%. Dari hasil perhitungan tersebut dapat dilihat peningkatan pada tahun 2015 dan tahun 2016 sebesar 2,62\%, hal ini dikarenakan oleh peningkatan pendapatan bunga dari Rp.3.030.490 menjadi Rp.3.108.758 dan penurunan beban bunga dari Rp.1.132.064 menjadi Rp.1.020.239. Pada tahun 2016 dan tahun 2017 mengalami peningkatan sebesar $1,42 \%$, hal ini dikarenakan oleh pendapatan bunga mengalami peningkatan daro Rp.3.108.758 menjadi Rp.3.208.572 dan beban operasional lainnya mengalami penurunan dari Rp.2.046.021 menjadi Rp.1.949.154. Dilihat dari Gross Profit Margin PT Bank SUMUT tahun 2015 sampai tahun 2017 memiliki kinerja yang baik karena mengalami peningkatan setiap tahunnya.

\section{Net Profit Margin}

Dari pengolahan data yang telah dilakukan, dapat disimpulkan bahwa besar Net Profit Margin, yaitu rasio antara net income dengan operating income PT Bank SUMUT pada tahun 2015 adalah 13,46\%, tahun 2016 adalah 15,16\%, dan tahun 2017 adalah 16,48\%. Dari hasil perhitungan tersebut dapat dilihat terjadi peningkatan rasio tahun 2015 dan tahun 2016 sebesar $1,70 \%$, hal ini dikarenakan oleh peningkatan pendapatan bersih dari Rp.464.935 menjadi Rp.584.500 dan peningkatan pendapatan operasional dari Rp.3.453.185 menjadi Rp.3.855.068. Pada tahun 2016 dan tahun 2017 juga mengalami peningkatan sebesar 1,32\%, hal dikarenakan oleh pendapatan bersih mengalami peningkatan dari Rp. 584.500 menjadi Rp.630.011. Dilihat dari Net Profit Margin PT Bank SUMUT tahun 2015 sampai tahun 2017 kinerja perusahaan baik karena mengalami peningkatan setiap tahunnya.

\section{Return on Equity Capital (ROU)}

Dari pengolahan data yang telah dilakukan, dapat disimpulkan bahwa besar Return on Equity Capital, yaitu rasio antara net income dengan Equity Capital PT Bank SUMUT pada tahun 2015 adalah 23,33\%, tahun 2016 adalah 21,50\%, dan tahun 2017 adalah 21,04\%. Dari hasil perhitungan tersebut dapat dilihat terjadi penurunan rasio tahun 2015 dan tahun 2016 sebesar $1,83 \%$, hal ini dikarenakan oleh peningkatan jumlah modal yang cukup signifikan dari Rp.1.992.417 menjadi Rp.2.719.149 sementara perolehan net income sangat kecil dari Rp.464.935 menjadi Rp.584.500. Pada tahun 2016 dan 2017 juga mengalami penurunan sebesar $0,46 \%$, hal ini dikarenakan oleh peningkatan jumlah modal yang lebih besar dari peningkatan perolehan net income. Dilihat dari Return on Equty Capital PT Bank SUMUT tahun 2015 sampai tahun 2017, manajemen bank kurang mampu mengelola modal untuk memperoleh net income, maka kinerja perusahaan kurang baik karena mengalami penurunan rasio setiap tahunnya.

\section{Return on Total Assets}

Dari pengolahan data yang telah dilakukan, dapat disimpulkan bahwa besar Return on Total Assets, yaitu rasio antara operating income dengan Total Assets PT Bank SUMUT pada tahun 2015 adalah 14,31\%, tahun 2016 adalah 14,73\%, dan tahun 2017 adalah 13,21\%. Dari hasil perhitungan tersebut dapat dilihat terjadi peningkatan rasio tahun 2015 dan tahun 2016 sebesar $0,42 \%$, hal ini dikarenakan oleh peningkatan operating income dari Rp.3.453.185 menjadi Rp.3.855.068 dan peningkatan total assets dari Rp.24.130.113 menjadi Rp.26.170.044. 
Pada tahun 2016 dan tahun 2017 mengalami penurunan rasio sebesar 1,52\%, hal ini diakibatkan oleh pengelolaan total assets yang meningkat dari Rp.26.170.044 menjadi Rp.28.931.824 tidak mampu menghasilkan income, sehinggan operating income mengalami penurunan dari Rp.3.855.068 menjadi Rp.3.822.595. Dilihat dari Return on Total Assets PT Bank SUMUT tahun 2015 sampai tahun 2017, manajemen bank kurang mampu mengelola aset untuk menghasilkan operating income, maka kinerja perusahaan kurang baik karena mengalami penurunan rasio.

\section{Rate Return on Loans (RoRoL)}

Dari pengolahan data yang telah dilakukan, dapat disimpulkan bahwa besar Rate Return on Loans (RoRoL) PT Bank SUMUT pada tahun 2015 adalah 17,89\%, tahun 2016 adalah 17,69\%, dan tahun 2017 adalah 17,38\%. Dari hasil perhitungan tersebut dapat dilihat terjadi penurunan rasio tahun 2015 dan tahun 2016 sebesar 0,20\% dan pada tahun 2016 dan 2017 juga mengalami penurunan rasio sebesar $0,31 \%$, hal ini dikarenaka oleh peningkatan total loans lebih besar dibandingkan peningkatan total Interest Income. Dilihat dari Rate Return on Loans (RoRoL) PT Bank SUMUT tahun 2015 sampai tahun 2017, kinerja perusaan kurang baik karena mengalami penurunan rasio setiap tahun.

\section{Rasio Solvabilitas}

Pengurus Bank dan Kreditor jangka pendek sangat berminat pada kemampuan perusahaan untuk membayar hutangnya dalam jangka pendek. Tetapi para kreditor jangka panjang atau pemegang saham jangka panjang selain berminat pada kondisi jangka pendek justru terutama berminat pada kondisi jangka panjang karena posisi keuangan jangka pendek tidak selalu paralel dengan posisi keuangan jangka panjang. Untuk mengetahui kondisi jangka panjang perusahaan, maka dilakukan analisis berdasarkan rasio Solvabilitas. Untuk lebih jelasnya berikut dijelaskan mengenai hasil dari perhitungan rasio solvabilitas pada PT Bank SUMUT.

\section{Primary Ratio}

Dari pengolahan data yang telah dilakukan dapat kita lihat bahwa Primary Ratio, yaitu rasio total ekuitas dengan total aset PT Bank SUMUT tahun 2015 adalah 8,26\%, tahun 2016 adalah 10,39\%, dan tahun 2017 adalah 10,35\%. Dari perhitungan tersebut dapat dilihat terjadi peningkatan pada tahun 2015 dan tahun 2016 sebesar 2,13\%, hal ini dikarenakan oleh peningkatan total equitas dari Rp.1.992.417 menjadi Rp.2.719.149 dan peningkatan pada total aset dari Rp.24.130.113 menjadi Rp.26.170.044. Tahun 2016 dan tahun 2017 mengalami penurunan rasio sebesar $0,04 \%$, hal ini dkarenakan oleh peningkatan total equitas dari $\mathrm{Rp}$ 2.719.149 menjadi $\mathrm{Rp} 2.994 .537$ dan peningkatan pada total aset dari Rp 26.170.044 menjadi Rp 28.931.824. Dilihat dari primary ratio PT Bank SUMUT tahun 2015 sampai tahun 2017 kinerja perusahaan kurang baik.

\section{Capital Ratio}

Dari pengolahan data yang telah dilakukan dapat kita lihat bahwa Capital Ratio, yaitu rasio total ekuitas dengan total loans PT Bank SUMUT tahun 2015 adalah 11,76\%, tahun 2016 adalah 15,47\%, dan tahun 2017 adalah 16,22\%. Dari perhitungan tersebut dapat dilihat terjadi peningkatan pada tahun 2015 dan tahun 2016 sebesar 3,71\%, hal ini dikarenakan oleh peningkatan ekuitas dari Rp.1.992.417 menjadi Rp.2.719.149 dan peningkatan total loans dari Rp.16.941.434 menjadi Rp.17.574.079. Tahun 2016 dan tahun 2017 juga mengalami peningkatan sebesar 0,75\%, hal ini dikarenakan oleh peningkatan ekuitas dari Rp.2.719.149 menjadi Rp.2.994.537 dan peningkatan total loans dari Rp.17.574.079 menjadi Rp.18.465.683. Dilihat dari capital ratio PT Bank SUMUT tahun 2015 sampai tahun 2017 kinerja perusahaan baik. 


\section{Capital Adequacy Ratio 2 (CAR 2)}

Dari pengolahan data yang telah dilakukan dapat kita lihat bahwa Capital Adequacy Ratio (CAR 2) PT Bank SUMUT tahun 2015 adalah 9,54\%, tahun 2016 adalah 9,55\%, dan tahun 2017 adalah 9,61\%. Dari perhitungan tersebut dapat dilihat terjadi peningkatan pada tahun 2015 dan tahun 2016 sebesar $0,01 \%$, hal ini di karenakan adanya peningkatan pada equity capital, fixed assets, total loans, dan securities. Tahun 2017 juga mengalami peningkatan sebesar 0,06\%, hal ini dikarenakan oleh peningkatan equity capital, fixed assets, total loans, securities juga meningkat. Dilihat dari Capital Adequacy Ratio (CAR 2) PT Bank SUMUT tahun 2015 sampai tahun 2017 kinerja perusahaan baik.

\section{Capital Adequacy Ratio 3 (CAR 3)}

Dari pengolahan data yang telah dilakukan dapat kita lihat bahwa Capital Adequacy Ratio 3 (CAR 3) PT Bank SUMUT tahun 2015 adalah 10,54\%, tahun 2016 adalah 13,79\%, dan tahun 2017 adalah 13.31\%. Dari perhitungan tersebut dapat dilihat terjadi peningkatan pada tahun 2015 dan tahun 2016 sebesar 3,25\%, hal ini dikarenakan oleh peningkatan ekuitas dari Rp.1.992.417 menjadi Rp.2.719.149 dan peningkatan securities dari Rp.1.970.422 menjadi Rp.2.148.272. Tahun 2016 dan tahun 2017 mengalami penurunan sebesar 0,48\%, hal ini dikarenakan oleh peningkatan ekuitas dari Rp.2.719.149 menjadi Rp.2.994.537 dan peningkatan securities yang cukup siginifikan dari Rp.2.148.272 menjadi Rp.4.038.036.

\section{Simpulan}

Dilihat dari Rasio Likuiditas, kinerja keuangan PT Bank SUMUT cukup baik. Karena investing policy ratio mengalami peningkatan, banking ratio, loan to assets ratio, loan to deposits ratio mengalami penurunan, tetapi quick ratio dan cash ratio mengalami fluktuasi.

1. Dilihat dari Rasio Rentabilitas, kinerja keuangan PT Bank SUMUT kurang baik. Karena gross profit margin dan net profit margin mengalami peningkatan, tetapi return on equity capital dan rate return on loans mengalami penurunan, dan return on total assets mengalami fluktuasi.

2. Dilihat dari Rasio Solvabilitas, kinerja keuangan PT Bank SUMUT cukup baik. Karena capital ratio dan CAR 2 mengalami peningkatan tetapi primary ratio dan CAR 3 mengalami fluktuasi.

\section{Saran}

Dengan dilakukannya analisis rasio laporan keuangan pada PT Bank SUMUT periode 2015-2017, maka saran yang dapat diberikan penulis adalah pihak Manajemen Bank harus meningkatkan kinerjanya untuk memanajemen dana bank dengan baik sehingga rasio keuangan yang dimiliki bank akan lebih baik pada periode yang akan datang.

\section{DAFTAR PUSTAKA}

Darmawi, Herman. 2011. Manajemen Perbankan. Jakarta: Bumi Aksara.

Fahmi, Irham. 2017. Analisis kinerja keuangan. Bandung: Alfabeta.

Harahap, Sofyan Syafri. 2011. Analisis Kritis Atas Laporan Keuangan.

Jakarta: PT Raja Grafindo Persada.

Hery, 2015. Analisis Laporan Keuangan. Yogyakarta: CAPS (Center of Academic Publishing Service)

Ismail. 2014. Akuntansi Bank. Jakarta: Kencana Prenadamedia Group.

Kasmir, 2008. Analisis Laporan Keuangan. Jakarta: PT Raja Grafindo Persada.

Martani, Dwi, dkk. 2012. Akuntansi Keuangan Menengah Berbasis PSAK.

Jakarta: Salemba Empat.

Mulyadi. 2001. Akuntansi Manajemen konsep, manfaat, dan rekayasa. Jakarta:

Salemba Empat. 
Munawir, S. 2007. Analisa Laporan Keuangan. Yogyakarta: Liberti Yogyakarta. Pandia, Frianto. 2012. Manajemen Dana dan Kesehatan Bank. Jakarta: PT Rineka Cipta.

Sanusi, Anwar. 2014. Metodologi Penelitian Bisnis. Jakarta: Salemba Empat

Siamat, Dahlan. 2005.Manajemen Lembaga Keuangan. Jakarta: Fakultas Ekonomi Universitas Indonesia.

Sugiyono, 2014. Metode Penelitian Pendidikan. Bandung: Alfa Beta.

Wardiah, Mia Lasmi. 2013. Dasar-Dasar Perbankan. Bandung: Pustaka Setia 